ISSN: 1858-4837;E-ISSN: 2598-019X

Volume 16, Nomor 1 (2021)

https://jurnal.uns.ac.id/region

DOI: 10.20961/region.v16i1.24696

\title{
Penerapan genius loci pada pengembangan Desa Pahat Batu Tamanagung
}

\author{
The application of genius loci on the development of Pahat Batu Tamanagung \\ Village
}

\author{
R A K Muna ${ }^{1}$, K N Handayani ${ }^{1}$, M Suastika $^{1}$ \\ ${ }^{1}$ Program Studi Arsitektur, Fakultas Teknik, Universitas Sebelas Maret
}

Corresponding author's email: ridhoakm@gmail.com

\begin{abstract}
Abstrak. Desa Tamanagung merupakan kawasan perintis kerajinan pahat batu di Kabupaten Magelang sejaktahun 1953 yang terus berkembang hingga saat ini. Empat puluh tujuh sanggar pahat dengan 144 orang pengrajin di Desa Tamanagung untuk saat ini tidak terfasilitasi sepenuhnya. Kondisi workshop dan galeri yang tidak dibangun dengan prioritas memadai sebagai wadah kegiatan pahat merupakan alasan utama untuk pengembangan kawasan. Kebutuhan utama pengembangan kawasan yaitu melalui penguatan citra kawasan bertujuan untuk mendukung pemasaran serta intrepetasi aktivitas budaya di lokasi. Zoning kawasan eksisting yang tumbuh organik, tampilan bangunan yang tidak representatif serta peruangan yang tidak dapat teridentifikasi merupakan permasalahan yang perlu diselesaikan. Pengembangan kawasan dengan penguatan citra kawasan tersebut pada akhirnya dicapai dengan (1) perencanaan zoning kawasan; (2) perancangan tampilan bangunan; (3) perancangan. Kriteria perencanaan dan perancangan kawasan menerapkan studi genius loci untuk mendapatkan citra kawasan dan bangunan yang sesuai dengan konteks tempat. Metode penelitian dilakukan dengan studi literatur teori genius loci dan uraian konsep desainnya, observasi lapangan melalui pemetaan serta pengamatan terhadap kondisi fisik bangunan dan aktivitas pahat, wawancara terhadap pelaku industri dari 5 sanggar pahat, tokoh masyarakat serta regulator. Hasil studi genius loci menemukan dua proses utama yaitu proses orientasi dan proses identifikasi. Proses orientasi diterapkan pada pengolahan zoning kawasan sedangkan proses identifikasi diterapkan pada peruangan dan tampilan bangunan. Proses orientasi pada perancangan zoning kawasan mempertimbangkan alur sirkulasi eksisting, jenis user (insider/outsider) serta ketersediaan lahan. Proses identifikasi pada perancangan tampilan bangunan dan peruangan mempertimbangkan karakteristik eksisting dan kebutuhan aktivitas.
\end{abstract}


Kata Kunci: Genius Loci, Kerajinan Pahat Batu, Pengembangan Kawasan, Proses Orientasi, Proses Identifikasi

\begin{abstract}
Tamanagung Village is a pioneer for stone carving crafts in Magelang Regency since 1953, which has continued to develop until today. Forty-seven stone carving workshops with 144 craftsmen are not fully facilitated. The workshops and galleries condition that are not built sufficiently to accommodate sculpting activities is the main reason for the development. The main need is image strengthening which aims to support marketing and interpretation of cultural activities. Existing area zoning that grew organically, unrepresentative buildings appearance, and unidentified spaces are problems that need to be resolved. Regional development by image strengthening is achieved by zoning planning, building appearance design, and area design. The planning and design criteria apply a genius loci study to obtain an image of the area and buildings that are in accordance with the context of the place. The research method was carried out by literature study of genius loci theories and descriptions of their design concepts, field observations through mapping, and observations of the buildings' physical condition and chisel activities, interviews with industry players from 5 carving studios, community leaders, and regulators. The study found two main processes, the orientation, and identification process. The orientation process is applied to zoning processing in the area, while the identification process is applied to the building space and appearance. The orientation process in zoning area design considers the existing circulation flow, the user type (insider/outsider), and land availability. The identification process in designing the building appearance and space takes into account existing characteristics and activity requirements.
\end{abstract}

Keywords: Genius Loci; Identification Process; Orientation Process; Stone Carving Crafts

\title{
1. Pendahuluan
}

Desa Tamanagung adalah kawasan kerajinan pahat batu yang paling mencolok dibandingkan dengan kawasan pahat batu lain di Kabupaten Magelang. Hal itu teridentifikasi dari data bahwa sebagian besar pengrajin dan sanggar pahat di Kabupaten Magelang terdapat di Desa Tamanagung [1]. Kerajinan pahat batu Tamanagung muncul sejak tahun 1953 ditandai dengan kemunculan sanggar pahat pertama di tahun tersebut. Sejak saat itu perkembangan kerajinan di Desa Tamanagung kemudian menyebar dan bersinergi dengan kawasan pahat lain.

Pengembangan kawasan pahat batu Desa Tamanagung adalah suatu bentuk dukungan terhadap aktivitas ekonomi dan nilai budaya yang tidak mendapatkan fasilitas yang cukup dibandingkan potensi yang ada. Potensi ekonomi di Desa Tamanagung dapat dilihat dari terdapatnya 47 sanggar pahat di desa ini yang terdapat 144 orang pengrajin dengan nilai

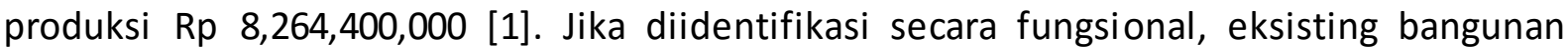
tersebut terdiri dari 2 (dua) macam fungsi yaitu bangunan workshop dan galeri. Bangunan yang mewadahi aktivitas pemahatan adalah bangunan workshop, dan bangunan yang 
berfungsi untuk memanjang produk pahat diinterpretasikan sebagai galeri. Sebagian besar dari bangunan-bangunan tersebut adalah bangunan semi permanen yang dibangun tanpa prioritas memadai sebagai suatu bangunan workshop ataupun galeri. Hal tersebut diidentifikasi dari elemen-elemen bangunannya mulai dari penutup bangunan yang sebagian besar menggunakan terpal atau asbes, struktur penahan menggunakan bambu atau kayu dan alas bangunan yang seringkali tidak berlantai.

Penerapan genius loci dalam pengembangan kawasan bertujuan untuk membantu penguatan citra kawasan yang sesuai dengan konteks tempat, baik dalam skala kawasan maupun bangunan. Penerapan genius loci tersebut didasari akan kebutuhan utama dari pengembangan kawasan Tamanagung yang memerlukan penguatan citra kawasan. Hal ini dikarenakan penguatan citra kawasan secara tidak langsung mendukung proses pemasaran produk pahat serta memudahkan akses bagi publik untuk mengapresiasi potensi yang ada di Desa Tamanagung.

Permasalahan yang perlu diselesaikan dalam pengembangan kawasan dengan penerapan genius loci meliputi zoning kawasan, peruangan serta tampilan bangunan. Zoning kawasan perlu ditata dikarenakan zoning eksisting yang tumbuh secara organik menyebabkan proses orientasi manusia terhadap tempat tidak berjalan sepenuhnya. Kedua, permasalahan peruangan bangunan yang berkaitan dengan proses identifikasi manusia terhadap tempat perlu untuk dicari model yang sesuai. Pada kondisi eksisting peruangan untuk aktivitas pahat batu seperti area produk, area material, area pahat dan area lain tidak mudah teridentifikasi. Ketiga, bangunan-bangunan eksisting yang tidak memadai perlu untuk memiliki tampilan yang representatif. Pada tampilan bangunan-bangunan ini sangat berpengaruh dalam proses identifikasi manusia terhadap tempat.

\section{Metode}

Penelitian diawali dari menetapkan latar belakang penelitian yang merupakan hasil eksplorasi dari observasi lapangan di Desa Tamangung, wawancara dengan pelaku industri, observasi media mengenai perkembangan industri pahat batu Tamanagung dan studi dokumen mengenai perencanaan industri pahat di Kabupaten Magelang. Hasil eksplorasi tersebut kemudian menjadi acuan dalam menentukan permasalahan yang perlu diselesaikan dalam penelitian (Gambar 1).

Observasi lapangan di Desa Tamanagung menghasilkan peta studi, data kondisi fisik bangunan eksisting serta detail aktivitas eksisting. Studi dokumen mendapatkan data statistik industri pahat batu di Kabupaten Magelang, informasi kebijakan perencanaan kawasan serta peta eksisting Desa Tamanagung. Wawancara terhadap pelaku industri dari 5 sanggar berbeda, tokoh masyarakat, regulator serta perwakilan perkumpulan masyarakat mendapatkan informasi mengenai permasalahan dan detail aktivitas pahat batu di Desa Tamanagung.

Alur penelitian yang dapat dilihat pada Gambar 1 selanjutnya adalah studi literatur mengenai genius loci. Studi literatur tersebut kemudian akan menjadi pedoman prosedural dalam penyelesaian masalah yang telah ditentukan sebelumnya. Acuan literatur tersebut 
antara lain: (1) Sense of Place, Authenticity and Character: A Commentary [2]; (2) Kajian Genius Loci dengan Fenomenologi Arsitektur Studi Kasus: Kawasan Kesawan [3]; (3) Lost in Place: On Place Theory and Landscape Architecture [4]; (4) Responsive Environments [5]; (5) Genius Loci: Towards a Phenomenology of Architecture [6]; (6) Pusat Kebudayaan sebagai Wadah Seni Pertunjukan dengan Pendekatan Genius Loci di Kotagede [7]. Secara umum dari tinjauan tersebut dapat diketahui bahwa konsep genius loci pada perancangan bangunan arsitektur dalam aplikasinya adalah pengaturan proses orientasi dan identifikasi manusia terhadap elemen-elemen tempat.

\section{KERAJINAN PAHAT BATU TAMANAGUNG}

Desa Tamanagung adalah kawasan kerajinan pahat batu dengan jumlah pengrajin terbanyak di Kabupaten Magelang. altivitas ekonomi dan budaya di kawasan pahat batu Desa Tamanagung tidak mendapatkan fasilitas yang cukup. sehingga membutuhkan suatu pengembangan

\section{PERMASALAHAN}

kebutuhan utama pengembangan kawasan yaitu melalui penguatan citra kawasan untuk mendukung pemasaran serta intrepetasi aktivitas budaya di lokasi. dalam mencapai tujuan tersebut perlu untuk melakukan perancangan zoning kawasan, peruangan serta tampilan bangunan.

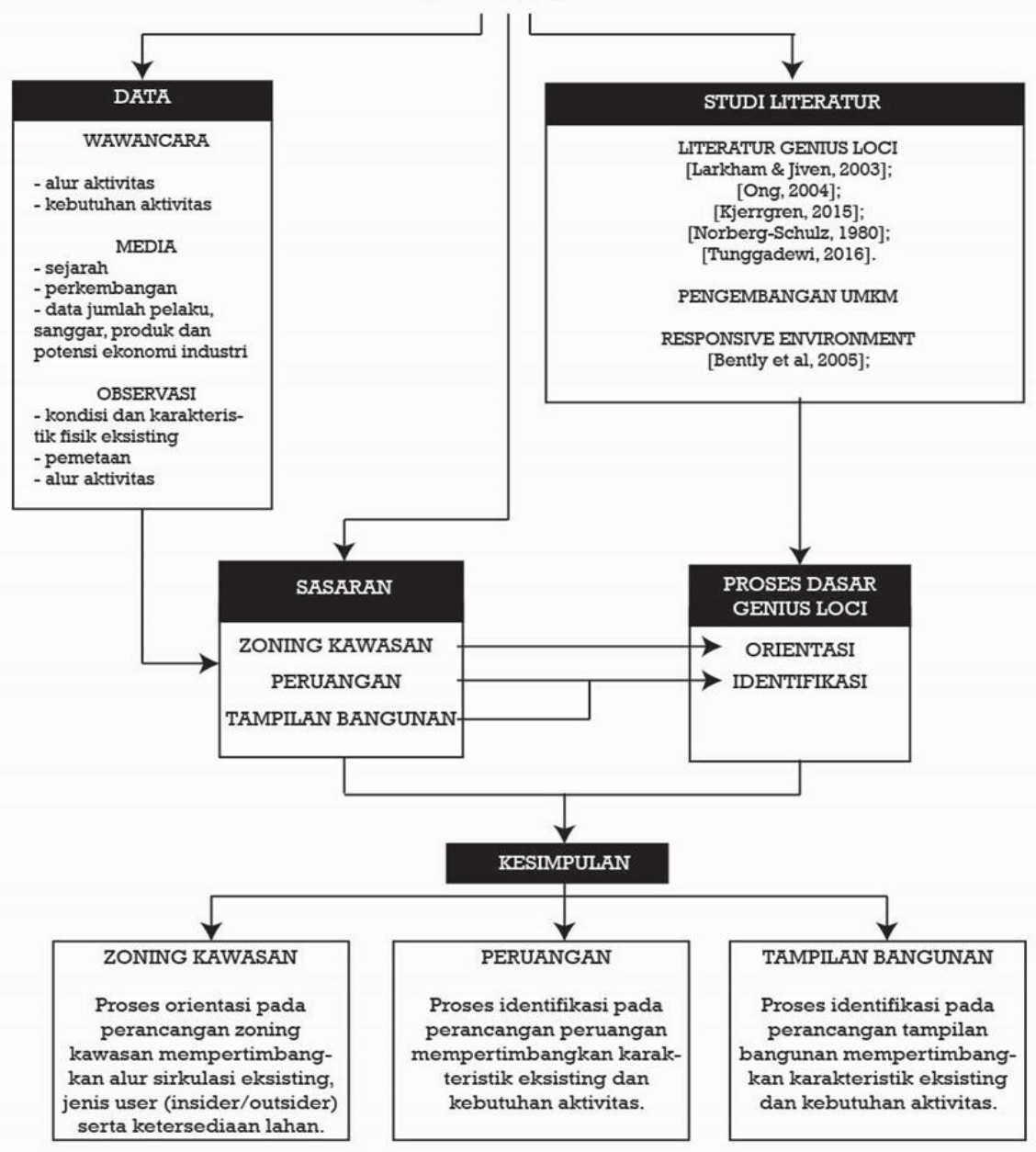

Gambar 1. Alur Penelitian dalam Penerapan Desain Genius Loci pada Kawasan Kerajinan Pahat Batu Tamanagung. 


\section{Hasil dan pembahasan}

Penerapan genius loci dalam pengembangan kawasan bertujuan untuk membantu penguatan citra kawasan yang sesuai dengan konteks tempat, baik dalam skala kawasan maupun bangunan. Genius loci atau spirit of place dideskripsikan sebagai representasi kesan yang manusia rasakan terhadap tempat, dipahami sebagai semua nilai-nilai fisik maupun simbolik di alam dan lingkungan manusia [2]. Konsep genius loci pada perancangan bangunan arsitektur dalam aplikasinya adalah pengaturan proses orientasi dan identifikasi manusia terhadap elemen-elemen tempat. Proses orientasi adalah suatu sistem pembentukan imaji lingkungan yang difasilitasi oleh struktur spasial dasar. Sedangkan proses identifikasi adalah skemata persepsi manusia terhadap tempat, dimana persepsi tersebut didasari oleh pengalaman manusia pada suatu tempat dalam periode waktu yang telah dilalui sebelumnya [6].

Jika didasari oleh permasalahan pengembangan kawasan, maka perlu diuraikan kebutuhan fungsi bangunan-bangunan sebagai media pengembangan kawasan. Jika didasari oleh observasi dan wawancara di lokasi penelitian maka aktivitas yang perlu diwadahi terdiri dari 2 tipe yaitu aktivitas ekonomi dan aktivitas budaya dimana penjabaran aktivitas dan fungsi bangunan yang mewadahinya ditunjukan seperti pada Gambar 2. Zoning kawasan dan peletakan fungsi-fungsi tersebut akan dibahas pada pembahasan poin 3.1. Sedangkan untuk tampilan dan pengaturan peruangan akan dijelaskan pada poin 3.2 dan 3.3.

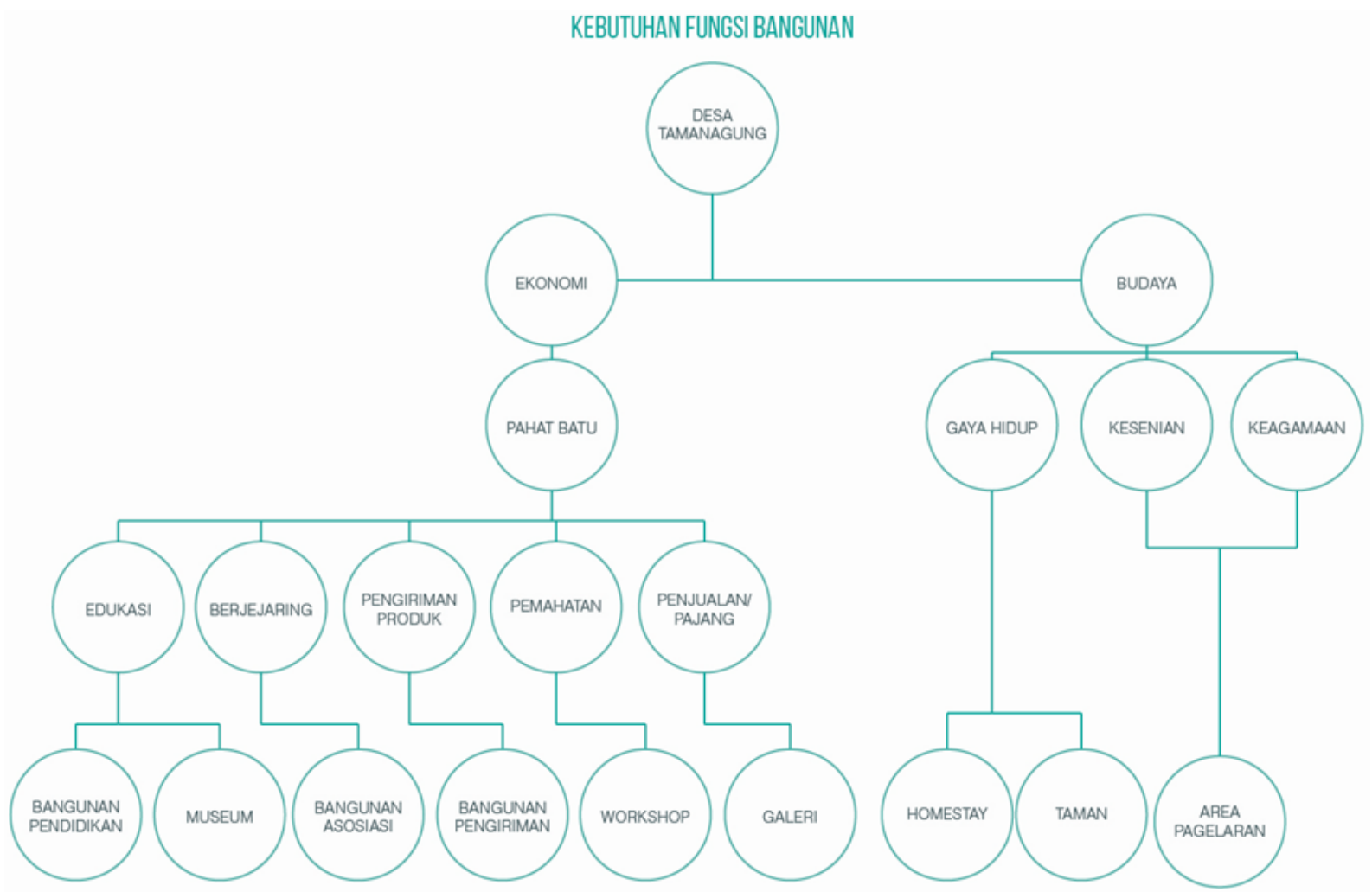

Gambar 2. Kebutuhan fungsi bangunan dalam pengembangan kawasan. 
Kawasan kerajinan pahat batu terletak di Desa Tamanagung, Kecamatan Muntilan, Kabupaten Magelang, Jawa Tengah. Kegiatan industri ini sendiri tersebar ke dalam 5 dusun di Desa Tamanagung di antaranya yaitu Dusun Dukuh, Ngawisan, Ngadiretno, Tejowarno, dan Prumpung. Penelitian kemudian dibatasi pada Dusun Tejowarno dan Sidoharjo (Prumpung) dengan pertimbangan bahwa pada 2 (dua) dusun tersebut terdapat sanggar pahat terbanyak, akses jalan utama dan nilai historis dari perkembangan pahat batu di dusun-dusun tersebut. Batasan area penelitian tersebut ditunjukan pada Gambar 3.

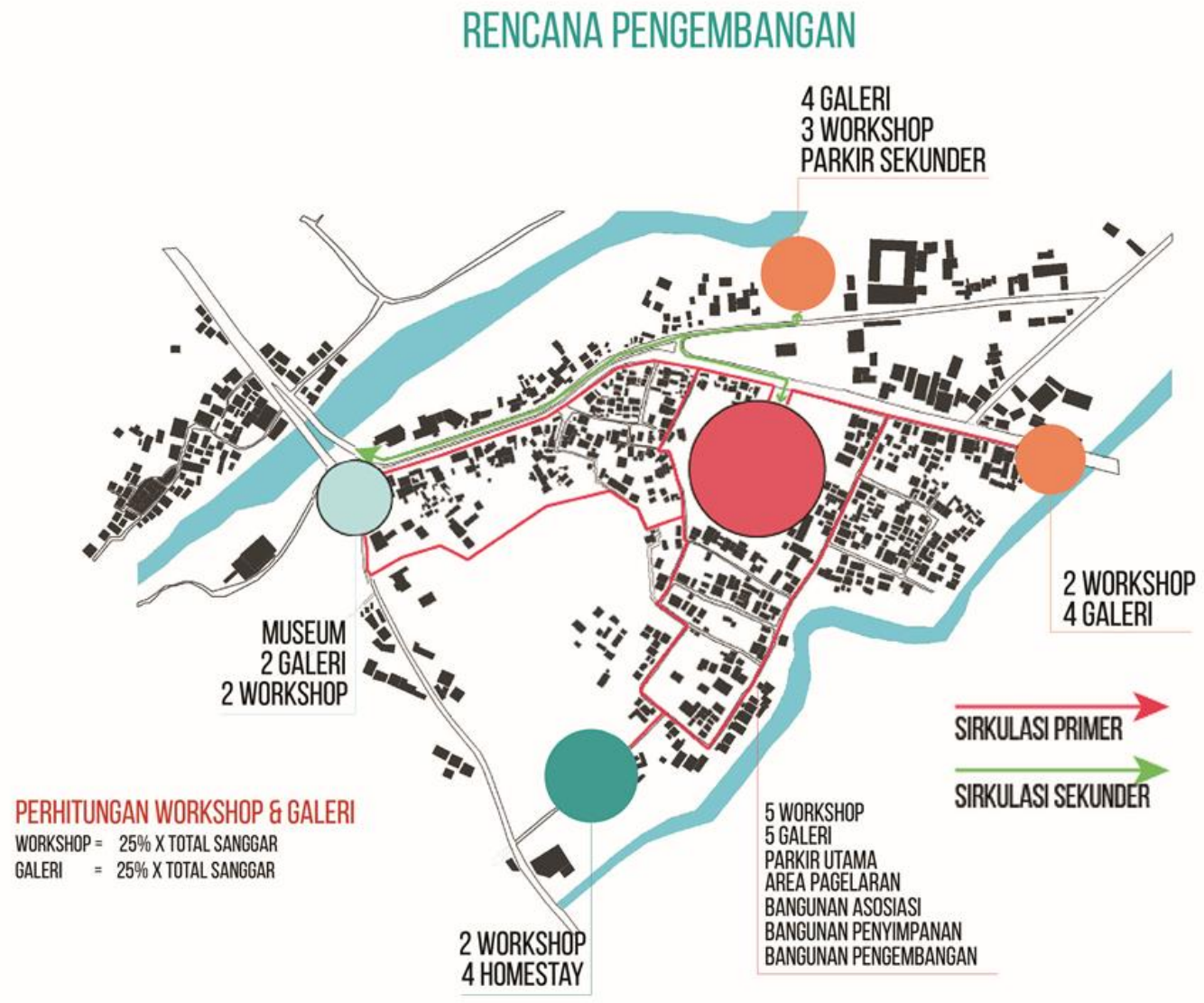

Gambar 3. Tahapan perencanaan zoning kawasan.

\subsection{Proses orientasi pada perencanaan zoning kawasan}

Berdasarkan Norberg-Schulz [6], proses orientasi adalah suatu sistem pembentukan imaji lingkungan yang difasilitasi oleh struktur spasial dasar. Struktur spasial dasar (boundary) yang menjadi objek orientasi manusia dapat ditemukan dalam konsep Lynch [8] tentang node, path, dan distrik. Lebih lanjut, jika diuraikan dalam Kjerrgren [4], zoning kawasan dalam konsep genius loci perlu untuk mempertimbangkan jenis subjek (user). Dimana subjek dibedakan menjadi 2 (dua) jenis yaitu insider dan outsider. Sehingga dalam penerapannya, proses orientasi dimunculkan dalam kawasan melalui; (1) pembagian zona perencanaan berdasarkan sirkulasi kawasan, kecenderungan user (insider/outsider), eksisting kegiatan, serta ketersediaan lahan untuk pengembangan; (2) penetapan fungsi-fungsi pengembangan dan akses sirkulasi baru; (3) Rancangan jalur sirkulasi dan node yang bisa berupa signage, pagar, material ataupun gerbang. 
Secara umum di lokasi terdapat 3 jenis jalan (path), yaitu jalan provinsi, jalan umum dan juga jalan kampung. Alur sirkulasi tersebut digunakan dalam memperkirakan pencapaian dan alur sirkulasi kawasan yang direncanakan. Jika berdasarkan jenis pengguna jalan, maka kemudian dapat ditentukan kecenderungan zona insider dan user outsider. Gambaran penggunaan lahan eksisting digunakan dalam menentukan peletakan site pengembangan yang sesuai dengan fungsi bangunan di sekelilingnya untuk membentuk kesan lingkungan yang solid. Karakteristik jalan provinsi yang berbeda arus kemudian turut men dorong kebutuhan akan dua area kedatangan. Dari kedua area kedatangan tersebut kemudian ditarik suatu jalur ke ujung-ujung kawasan perencanaan untuk menyamaratakan akses di dalam kawasan.

Dari tahapan-tahapan tersebut maka dapat diperlihatkan alur sirkulasi kawasan dan pembagian zoning perencanaan seperti pada Gambar 3.

Jika dikaitkan dengan peletakan bangunan-bangunan pengembangan pada zoning perencanaan kawasan, maka pertimbangan-pertimbangannya adalah ketersediaan lahan, karakteristik lahan (inside/outside) dan juga alur sirkulasi yang telah direncanakan sebelumnya. Dari daftar jenis bangunan pengembangan (Gambar 1), asumsi bangunan yang diperlukan masing-masing satu, sedangkan untuk bangunan workshop dan galeri berjumlah sekitar $25 \%$ dari total sanggar yaitu 47 sanggar, serta homestay yang berjumlah 4 . Dari pertimbangan-pertimbangan tersebut maka peletakan fungsi bangunan pada rencana pengembangan kawasan dapat dilihat pada Gambar 3.

Rancangan jalur sirkulasi dan node yang berupa signage, pagar ataupun gerbang adalah suatu cara dalam membentuk orientasi user terhadap kawasan secara holistik. Dimana model yang dijadikan acuan adalah karakteristik eksisting dari masing-masing objek tersebut. Secara umum penerapan karakteristik eksisting tersebut dapat dilihat pada Gambar 4.

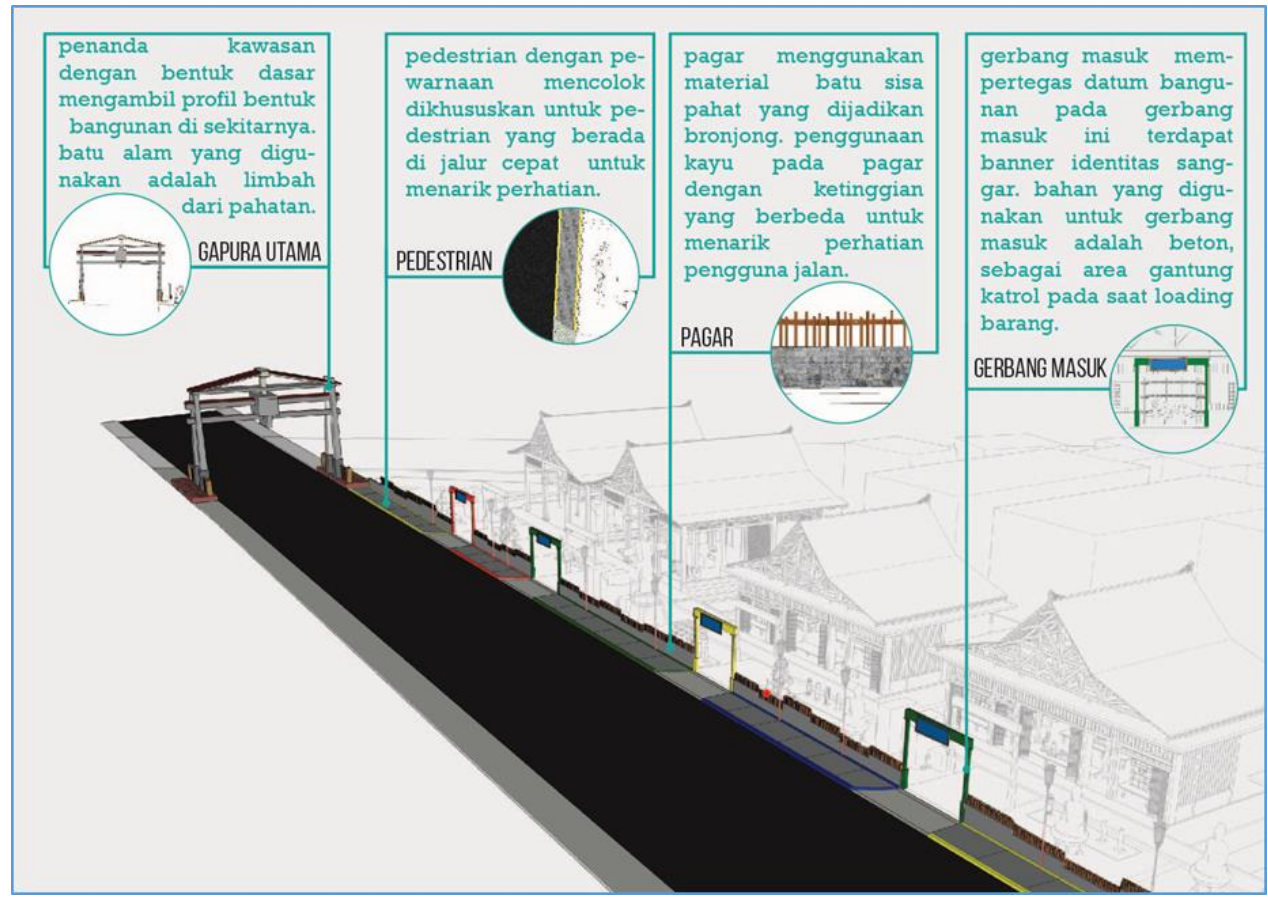

Gambar 4. Rancangan jalur sirkulasi.

Received : October 22, 2018; Accepted: October 31, 2018; Available online: January 30, 2021

Copy right $\odot 2021$, REGION: Jurnal Pembangunan Wilay ah dan Perencanaan Partisipatif 


\subsection{Proses identifikasi pada perancangan tampilan bangunan}

Proses identifikasi adalah skemata persepsi manusia terhadap tempat, dimana persepsi tersebut didasari oleh pengalaman manusia pada suatu tempat dalam periode waktu yang telah dilalui sebelumnya. Dalam prosesnya, persepsi manusia ditentukan dari 2 (dua) faktor yaitu faktor objek dan faktor subjek; (1) faktor objek adalah faktor keberadaan elemenelemen karakter sebagai objek yang dipersepsikan manusia. Elemen-elemen karakter tersebut secara fisik dibentuk oleh fasad, moda konstruksi, material, ekspresi simbolik serta konstitusi dan artikulasi formal [3]. Karakter visual tersebut jika dijabarkan oleh Bently et al [5] ditunjukan dalam konfigurasi, ritme vertikal, ritme horizontal, bukaan dan skylines; (2) faktor subjek adalah faktor keterikatan manusia terhadap tempat yang dipersepsikannya. Perbedaan jenis keterikatan tersebut dalam praktiknya akan membedakan pola aktivitas dari pengguna (user). Secara umum subjek dibedakan menjadi 2 (dua) jenis yaitu insider dan outsider [4]. Berikut merupakan tampilan aplikasi proses identifikasi pada tampilan bangunan yang dapat dilihat pada Gambar 5 .

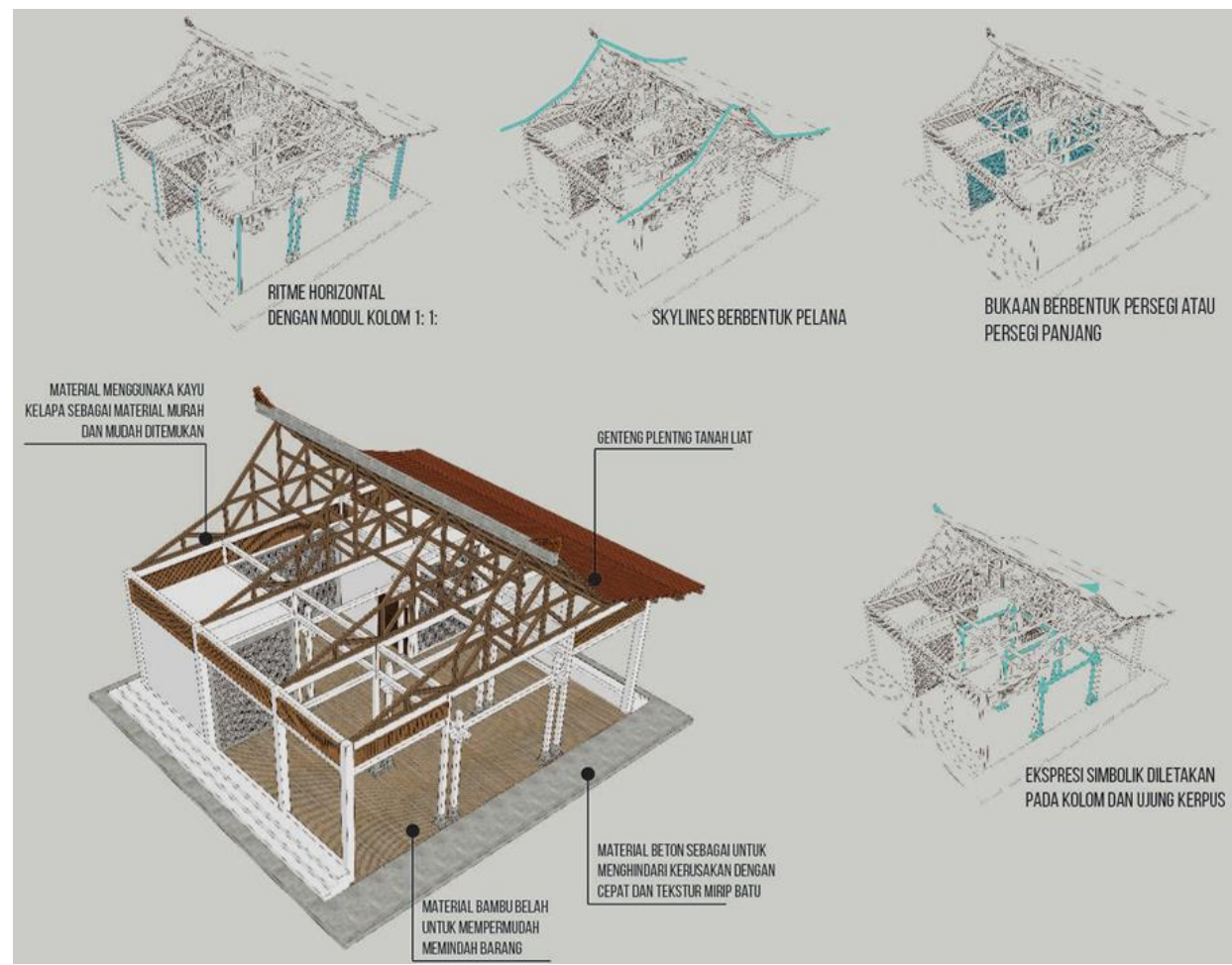

Gambar 5. Aplikasi proses identifikasi pada tampilan bangunan.

Aplikasi proses identifikasi yang diterapkan pada pembentukan tampilan bangunan adalah ritme vertikal, ritme horizontal, ekspresi simbolik, material, bukaan dan skylines. Dimana tahapan awal dalam penerapan konsep ini adalah dengan melakukan observasi eksisting dari masing-masing elemen tersebut dimana dapat dilihat pada Tabel 1. Setelah itu, perlu diketahui juga kriteria fungsional dari masing-masing kegiatan yang akan diwadahi dalam suatu rancangan bangunan yang dapat dilihat pada Tabel 2. Sehingga, karakteristik eksisting yang telah diobservasi disesuaikan dengan syarat fungsional yang telah ditentukan untuk mendukung prioritas bangunan sebagai wadah kegiatan. 
Tabel 1. Karakteristik eksisting pada aspek tampilan bangunan.

\begin{tabular}{|c|c|}
\hline $\begin{array}{l}\text { Aspek } \\
\text { Tampilan } \\
\text { Bangunan }\end{array}$ & Karakteristik Eksisting \\
\hline Bukaan & $\begin{array}{l}\text { Berbentuk pers egi dan persegi panjang. Merupakan komposisi linear simetris dengan orientasi } \\
\text { ke arah atas/komposisi grid. Ma terial ya ng digunakan pada lis a dalah kayu, pada panel yaitu } \\
\text { kaca \& kayu. Detail berupa aksen di lis dengan motif dasar tanaman. }\end{array}$ \\
\hline $\begin{array}{l}\text { Ritme } \\
\text { vertikal }\end{array}$ & $\begin{array}{l}\text { Terdapat rasio kepala: badan: kaki berkisardengan proporsi terbesar pada bagian kepala } \\
\text { yaitu berkisar } 5: 3.5: 1 \text {. Dengan catatan bagian kaki merupakan elevasi berkisar } 0.5-1 \mathrm{~m} \text {. } \\
\text { Membentuk komposisilinear dengan orientasi keatas, begitu pula bukaan. Datum ditenga } \mathrm{h} \\
\text { dengan kecendrungan simestris }\end{array}$ \\
\hline $\begin{array}{c}\text { Ritme } \\
\text { horizontal }\end{array}$ & $\begin{array}{l}\text { Ritme horizontal ditentukan oleh struktur, biasanya modular. Terda pat rasio 1:1:1 dst yang } \\
\text { dibentuk ol eh panel kolom. Detail seperti bukaan dan aksen membentuk komposisi terpusat } \\
\text { a tau linear. Datum di tengah dengan kecendrungan simetris }\end{array}$ \\
\hline Material & $\begin{array}{l}\text { Pada bagian kaki, material yang digunakan bervariasi antara belahan bambu, rabat beton, } \\
\text { kayu, batu alam, lantai keramik, tegel motifgeometris atau motif tanaman. Sedangkan pada } \\
\text { bagian badan dinding plester, partisi bambu dan atau kayu, batu alam. Untuk atap } \\
\text { menggunakan genteng tanah liat, asbes, dak beton. }\end{array}$ \\
\hline $\begin{array}{l}\text { Eksptesi } \\
\text { simbolik }\end{array}$ & $\begin{array}{l}\text { Di bagian kolom ataupenutup lantai terka dang ditemukan simbol-simbol. Seperti motif di } \\
\text { umpak, keramik bermotif, a tau batu alam yang dipasang vertikal dengan relief tertentu. } \\
\text { Sedangkan, di bagian ba dan dan kepala bangunan, simbol digunakan untuk mempertegas } \\
\text { profil dan ornamentasi. Digunakan di bagian dinding, partisi, bukaan, ataukolom dengan motif } \\
\text { benda alam, tanaman atau hewan, tokoh pahlawan dan makhluk mitologi dengan makna } \\
\text { tertentu. Sedangkan bagian kepala dapat ditemukan di bagian tepi dari atap. }\end{array}$ \\
\hline Skylines & $\begin{array}{l}\text { Atap pel a na a tau joglo di bentuk dari sudut lancip. Untuk pelana berkisar da ri } 15-35^{\circ} \text { da nuntuk } \\
\text { untuk joglo dari dua sudut, } 15-30^{\circ} \text { dan sudut a tap berikutnya lebih tajam } 30-60^{\circ}\end{array}$ \\
\hline
\end{tabular}

Tabel 2. Kebutuhan fungsional pada bangunan pahat, pamer dan pengiriman.

\begin{tabular}{cl}
\hline $\begin{array}{c}\text { Aspek } \\
\text { Tampilan } \\
\text { Bangunan }\end{array}$ & \multicolumn{1}{c}{ Kebutuhan Fungsional } \\
\hline Tampilan & $\begin{array}{l}\text { Ta mpilan yang menimbulkan kesan terbuka yang memberi view maksimal untuk mena mpilkan } \\
\text { aktivitas yang dilakukan di dalam ba ngunan. Kebutuhan lainnya a dalah bangunan perlu memiliki } \\
\text { ketinggian lebih ti nggi daripada rata-rata, dengan asumsi ketinggian minimal } 4 \text { meter. Hal ini } \\
\text { untuk mengantisipasi keberadaan patung yang berukuran besar dan keberadaan alat katrol. }\end{array}$ \\
Material & $\begin{array}{l}\text { Penggunaan material lantai yang ti dakmudah rusak akan beban berat. Kebutuhan lain adalah } \\
\text { material memiliki daya ges ek yang rendah untuk memudahkan pemindahan material batu. } \\
\text { Material struktur ditubuhkan material yang kokoh dalam menahan beban vertikal, dima na hal } \\
\text { ini untuk memfasilitasi proses pemindahan material menggunakan katrol. Untuk keseluruhan }\end{array}$ \\
lainnya, penggunaan material yang diutamakan adalah menggunakan material yang secara \\
Pelatif murah dan mudah didapatkan.
\end{tabular}



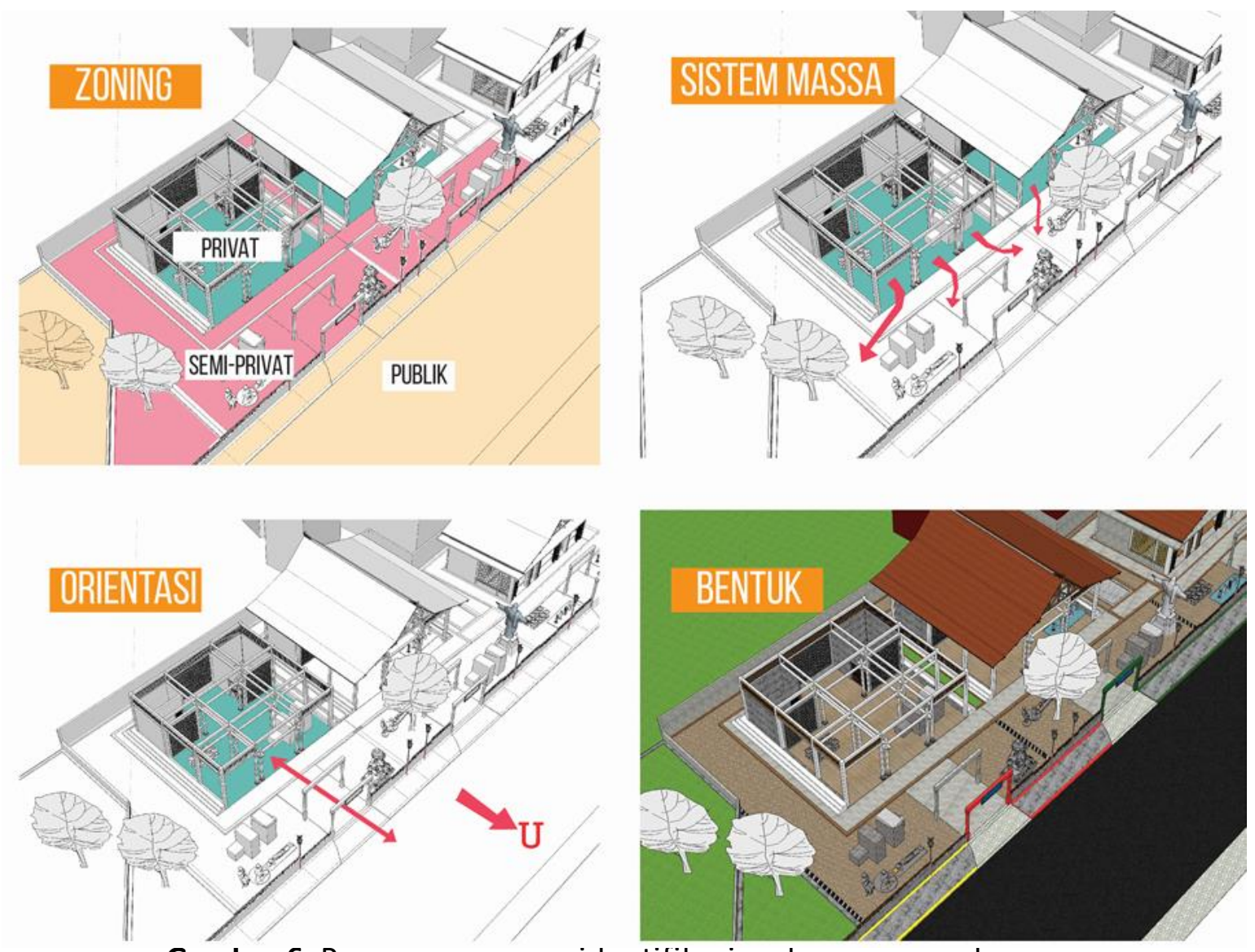

Gambar 6. Penerapan proses identitikasi pada peruangan bangunan.

Secara umum, tidak semua karakteristik pada Tabel 1 dapat diterapkan seutuhnya. Terlebih pada bangunan yang digunakan sebagai wadah kegiatan pahat, pamer dan pengiriman. Dimana, bangunan dengan tipe kegiatan tersebut memiliki syarat-syarat fungsional tertentu seperti ditunjukan pada Tabel 2.

Setelah diketahui kriteria fungsional dari bangunan tersebut, karakteristik eksisting yang telah diobservasi kemudian diseleksi disesuaikan dengan syarat fungsional yang telah ditentukan untuk mendukung prioritas bangunan sebagai wadah kegiatan. Aplikasi dari proses ini dapat dilihat pada Gambar 5.

\subsection{Proses identifikasi pada peruangan}

Aplikasi proses identifikasi yang diterapkan pada peruangan bangunan adalah konfigurasi, ekspresi simbolik dan ritme horizontal. Konfigurasi jika dijabarkan lagi dapat diuraikan dari pembatas ruang, zoning, komposisi, sistem ruang, orientasi dan bentuk. Eksisting dari masing-masing elemen identifikasi ruang tersebut dapat dilihat pada Tabel 3. Elemen identifikasi ruang eksisting tersebut kemudian disesuai kan dengan kriteria fungsional (Tabel 2). Sehingga, hasil penerapan dari konsep tersebut dapat dilihat pada Gambar 6.

Tabel 3. Konfigurasi ruang eksisting. 


\begin{tabular}{ll}
\hline $\begin{array}{c}\text { Elemen } \\
\text { Identifikasi } \\
\text { Ruang }\end{array}$ & \multicolumn{1}{c}{ Konfigurasi Ruang Eksisting } \\
\hline $\begin{array}{l}\text { Sistem } \\
\text { ruang }\end{array}$ & $\begin{array}{l}\text { Sistem ruang tidak dapat terlepas dari sistem massa, dimana sistem massa eksisiting } \\
\text { adalah sistem massa terlepas. Dengan begitu maka maka sistem ruang eksisting } \\
\text { adalah sistem ruang terlepas dengan ukuran ruang yang berkelompok relatif kecil, } \\
\text { kecenderungan berhubungan langsung dengan area luar, yang disambungkan } \\
\text { dengan selasar atau jalur sirkulasi. }\end{array}$ \\
Orientasi & $\begin{array}{l}\text { Orientasi ruang adalah tidak menghadap ke arah matahari secara langsung, } \\
\text { orientasi prioritas kedua adalah menghadap akses jalan paling ramai. }\end{array}$ \\
Bentuk & $\begin{array}{l}\text { Bentuk ruang persegi atau balok, dimana hal ini tidak terlepas dari moda konstruksi } \\
\text { eksisting yang memiliki kecenderuangan bentuk ruang persegi. Bentuk ruang } \\
\text { ruang }\end{array}$ \\
Persegi dan balok tersebut adalah bentuk ruang yang paling efisien
\end{tabular}

\section{Kesimpulan}

Berdasarkan analisis yang telah dijabarkan pada poin poin diatas maka dapat ditarik beberapa kesimpulan mengenai penerapan teori genius loci pada pengembangan desa pahat batu Tamanagung.

a) Konsep desain orientasi mencakup pembagian zoning pengembangan kawasan, perencanaan dan perancangan jalur sirkulasi. Zoning pengembangan kawasan didasari oleh alur sirkulasi eksisting, jenis user (insider/outsider) serta ketersediaan lahan. Perencanaan dan perancangan jalur sirkulasi didasari oleh eksisting kegiatan dan karakteristik jalur sirkulasi eksisting yang berupa signage, pagar, jalan ataupun gerbang.

b) Penerapan proses identifikasi pada desain tampilan bangunan didasari oleh karakteristik tampilan bangunan eksisting dan kebutuhan aktivitas. Karakteristik tampilan eksisting berfungsi sebagai alternatif-alternatif yang diseleksi berdasarkan kebutuhan aktivitas. Elemen karakteristik tampilan tersebut adalah bukaan, ritme vertikal, ritme horizontal, skylines, material dan ekspresi simbolik.

c) Penerapan proses identifikasi pada peruangan bangunan didasari oleh karakteristik peruangan eksisting dan kebutuhan aktivitas. Karakteristik peruangan eksisting berfungsi sebagai alternatif-alternatif yang diseleksi berdasarkan kebutuhan aktivitas. Elemen karakteristik peruangan tersebut adalah konfigurasi ruang, ekspresi simbolik dan ritme horizontal. Konfigurasi ruang tersebut terdiri dari sistem massa, zoning, orientasi, bentuk, pembatas dan komposisi ruang.

\section{Referensi}


[1] Disperindag Kabupaten Magelang 2014 Laporan IKM Kabupaten Magelang 2014 (Magelang)

[2] Larkham P J dan Jiven G 2003 Sense of Place, Authenticity and Character: A Commentary Journal of Urban Design 81 pp $67-81$ DOI: 10.1080/1357480032000064773

[3] Ong H I 2004 Kajian Genius Loci dengan Fenomenologi Arsitektur Studi Kasus: Kawasan Kesawan (Universitas Sumatera Utara)

[4] Kjerrgren L 2015 Lost in Place: On Place Theory and Landscape Architecture (Swedish University of Agricultural Sciences)

[5] Bently I, Alcock A, Murrain P, Mcglynn S dan Smith G 2005 Responsive environments (Cornwall: MPG Books Ltd)

[6] Norberg-Schulz C 1980 Genius Loci: Towards a Phenomenology of Architecture (New York: Rizzoli)

[7] Tunggadewi R Y, Hardiyati dan Kusumaningdyah N H 2016 Pusat Kebudayaan sebagai Wadah Seni Pertunjukan di Kotagede dengan Pendekatan Genius Loci Jurnal Arsitektura 142 DOI: 10.20961/arst.v14i2.9050

[8] Lynch K 1960 The Image Of the City (Massachusetts : Massachusetts Institute of Technology and the Oresident amd Fellows of Harvard College) 